\title{
Making Meaning of Religious Values in Preventing a Fatal Suicide Act of a Bisexual Youth with Borderline Personality Disorder: A Qualitative Study
}

\author{
Tience Debora Valentina ${ }^{1}$, Carla R Marchira ${ }^{2}$, Tina Afiatin ${ }^{3}$, Noor R Hadjam ${ }^{4}$
}

${ }^{1}$ Faculty of Psychology, Universitas Gadjah Mada; Departments of Psychology, Faculty of

Medicine, Universitas Udayana, ${ }^{2}$ Faculty of Medicine, Universitas Gadjah Mada

${ }^{3,4}$ Faculty of Psychology, Universitas Gadjah Mada

Submitted 8 June 2020 Accepted 4 January 2021 Published 26 April 2021

\begin{abstract}
Male adolescents of sexual minority groups often present mental health problems and suicidal behaviors. This qualitative study was conducted to explore how a bisexual youth with borderline personality disorder and multiple suicide attempts coped with his intention to die. Analysis was done using the Grounded Theory approach resulted in several themes. First, the pathway to suicidal behaviors; depicting the conflict between parents and the history of mother's suicide attempts made him felt disconnected with the family. Second, the feeling of not deserving loved although having the need to be loved and to love. Third, the ambivalence of his sexual orientations as he had strong desire to be with a man yet felt happy dating a girl. Fourth, the interpretation of religious values for preventing fatal suicidal act. He perceived that his suicide attempts failed because God wants him to stay alive. The discussion addresses the aspect of religiosity that obstructs suicidal behaviors in bisexual youths.
\end{abstract}

Keywords: bisexual; borderline personality disorder; qualitative study; religious values; suicidal behavior

Young people from sexual minority groups such as bisexual who conduct suicidal behaviors and live in a religious country like Indonesia experience many challenges. One of the challenges is rejection from their social environment because of their sexual orientation. Research conducted by Mavhandu-Mudzusi and Sandy (2015) in South Africa found that university students with lesbian, gay, bisexual, and transgender sexual orientations experienced religion-related stigma and were labeled 'sinful', 'devil', and 'belonging to the devil'. These students often skip classes, delay going to college and even attempted to suicide. They feel the fear of facing stigma and discrimination if they open themselves up, particularly about their sexual orientation as bisexual.

1Address for correspondence: tiencedebora@unud.ac.id 
Empirical studies have also elucidated the correlation between sexual orientations and $\mathrm{BPD}$, moreover in youths, although the correlation is not clear yet. Diagnostic Statistical Manual of Mental Disorder-5 (DSM-5) defines BPD as a personality disorder that indicates unstable patterns of interpersonal relationship, self-image, and emotions as marked by impulsiveness starting from early adulthood and appearing in different contexts (American Psychiatric Association, 2013). DSM-5 explains that one of the criteria of an individual having BPD is impulsiveness that potentially leads to self-destructive behaviors such as suicidal behaviors (American Psychiatric Association, 2013). Studies also provide evidence that individuals with BPD are often found in emergency rooms because of their suicidal behaviors or suicide attempts (Biskin \& Paris, 2012). Several factors triggering suicide attempt in people with BPD are interpersonal relationship (Aguirre, 2014; Brodsky et al., 2006); and difficulty in regulating emotions and impulsiveness (Terzi et al., 2017).

Adolescents from minority sexual orientations significantly showed characteristics of BPD, and bisexual adolescents had higher scores on the BPD characteristics than the score gained by homosexual adolescents (Reuter et al., 2016). Previous studies also revealed that individuals with BPD tend to exhibit homosexual or bisexual orientations (Reich \& Zanarini, 2008). Surprisingly, Rodriguez-Seijas et al. (2020) found the clinicians bias in the diagnosis of individuals from sexual minority groups, especially bisexual, who were more likely to diagnose BPD. The findings make clear the need to understand individuals from sexual minority groups, whether they actually experience psychopathology such as BPD, or whether their psychopathological symptoms are influenced by their sexual orientation, which is often linked to rejection of a more heterosexual society.

Although the correlation is still debated, the findings of previous research indicated that experiencing BPD as well as having bisexual orientation increasse the risk of committing suicide, especially in male adolescents. Lesbian, gay, and bisexual adolescents have the tendency of attempting to commit suicide rather than heterosexual ones (Hatzenbuehler, 2011). People from the sexual minority groups such as lesbian, gay and bisexual (LGB) show increased risk of suicidal behaviors such as suicide ideation, suicide plan, and suicide attempt during their lifetime rather than heterosexual people (Björkenstam et al., 2016; Plöderl et al., 2013; Stone et al., 2014). The results of systematic review and meta-analysis of 30 cross-sectional studies involving 21,201 adults from sexual minority groups in nonclinical settings in the United States, Canada, Europe, Australian and New Zealand found that LGB individuals conducted suicide attempts were as many as 20 percent (Hottes et al., 2016). Especially in bisexual group, suicide attempt showed bigger prevalence than in heterosexual group (Blosnich \& Bossarte, 2012; Bolton \& Sareen, 2011; Miranda-Mendizábal et al., 2017). Several factors of the general risk having correlation with suicide attempt in LGBT youths are depression and compulsive disorder, hopelessness and impulsiveness, and same-sex attraction at early age (Mustanski \& Liu, 2013). In addition, lesbian and gay individuals are more open about their sexual orientation than the bisexual ones, who tend to experience conflicts related to their sexual orientation (Lewis et al., 2009). 
Religious conflict experienced by bisexual adolescents is related to their religions' values or moral standards prevailing in the societies they live in. Indonesia is known as a religious country (The Jakarta Post, 2017). Religious teachings in Indonesia are conservatively perceived so that people's standpoints on LGBT are negative, discriminating or bullying (USAID \& UNDP, 2014). Although there is no data indicating Indonesian people's responses to bisexual people, most people reject homosexual people, who come from sexual minority group (Badgett et al., 2017). When facing religious or spiritual belief systems that exhibit rejection and disapproval to sexual minority groups, it is hard for these individuals to develop and accept sexual identities as lesbian, gay, and bisexual, which can cause psychological maladjustment (Page et al., 2013), and suicide ideation (Gibbs, 2015; Schuck \& Liddle, 2001). One of the factors causing LGBT youths to have suicidal tendency is the loss of friends due to their coming out (Puckett et al., 2017). This condition indicates that a bisexual person who lives in a religious society like Indonesia will encounter society rejection.

\section{Method}

This qualitative study involved a single participant, namely $\mathrm{Fe}$, a young man aged 22 years old, not married, attending bachelor's degree program in a state university in Yogyakarta. He came from a middle-class family. His father retired from a state-owned enterprise and his mother worked informally. Before attending education at the university level, he lived with his parents in a rural area in West Java. He moved to Yogyakarta to study. He lived in a boarding house for male students. His education and living costs were fully funded by his parents. He went home at least twice per semester, during semester break and holidays such as Eid. He is the youngest of three siblings. He has a married sister 8 years older than him and a brother who is 7 years older and is not married. He identified himself as a religious Moslem who actively participated in Moslem students' activities in campus, and even he became a leader of Moslem Students Organisation.

This participant was purposively selected from the mental health department of Dr. Sardjito Hospital in Yogyakarta. He was an outpatient of its psychiatric service. A month before the study, he was hospitalized for 10 days due to a suicide attempt through drugs overdose. First meeting was done a month after he left the hospital. During the study, or two months after the first suicide attempt, he conducted the second suicide attempt by hanging with a waistband. He conducted self-cutting on his hand and chest when the thoughts of dying were so strong. The result of clinical assessment from his psychiatrist showed that he had BPD and homosexual tendency. Until this article was written, he was still receiving counselling service and pharmacotherapy from the psychiatrist. This research has received approval from Medical and Health Research Ethics Committee (MHREC) Faculty of Medicine, Universitas Gadjah Mada, Indonesia, on $10^{\text {th }}$ of October 2017 with number of Ref: KE/FK/1099/EC/2017. The participant was given an informed consent sheet to be signed as willingness statement to participate in this study. 
Individual semi-structured interview was done with the participant to explore how he faced his strong intention to die. There were 7 questions concerning his suicidal behaviors, including about the situations triggering suicide attempts, how he perceived his BPD diagnosis, what he experienced in relation to his sexual orientation. Among those questions are: 1) In the last 6 months, did you seriously think, plan and attempt to commit suicide?; 2) What situation can inflict suicidal behavior?; 3) What do you think about yourself in relation with your BPD's diagnosis?; 4) What have changed in the relationship with your family following your suicide attempt?; 5) What have changed in your relationship with other people?; 6) What do you think about your sexual orientation?; 7) How do you perceive religious values when the strong desire to die comes up? The main researcher interviewed him alone in every session. It was done in a private room at the Faculty of Psychology, Universitas Gadjah Mada, as approved by him.

The meeting occurred three times and was recorded with a voice recorder. The recordings were then transcribed into verbatim. After the transcription was completed, all information concerning the details that could reveal his identity was deleted in order to keep the confidentiality. The transcript was in Indonesian language. The third was an opportunity for member checking as a measure to maintain the credibility of the data. Member checking was done by giving the participant a chance to read the verbatim and the analytical report of the interview. The participant could make clarification to confirm that the data analysis done by the researchers was correct as he had stated (Arora, 2017).

Grounded theory method was used to analyse the data (Glaser \& Strauss, 1967). The procedures of grounded theory have been designed to develop a set of integrated concept that provides a comprehensive theoretical explanation about social phenomena studied (Corbin \& Strauss, 1990). Data obtained were analysed using coding procedure, which is a process of transforming raw data into conceptual data (Corbin \& Strauss, 2008). It consists of several stages. First, it is open coding in which data are elaborated analytically to form categories and sub-categories; second, it is axial coding, which is a process of connecting one category to other category (Corbin \& Strauss, 2008). The last is selective coding, which is a process of combining all categories into one core category. In this study this procedure resulted in several themes.

\section{Results}

In this part several themes appearing in this study were illustrated. There were five main themes, namely (a) the pathway to becoming suicidal; (b) acceptance to Borderline Personality Disorder diagnosis, (c) feeling unworthy of love, (d) the ambivalence of sexual orientation, and (e) making meaning of religious values for overcoming fatal suicidal behaviors. Here we present the summary for each theme.

\section{The pathway to becoming suicidal}

The pathway to becoming suicidal describes some situations that become the risk factors to suicidal behaviors. Fe was raised in a middle-class family in an urban neighbourhood 
in West Java. When he entered adolescence, at the second grade of junior high school to be exact, his mother attempted to commit suicide. It was not her first attempt. He was told by his brother that her mother had done it before he was born. Since his mother's suicide attempt, he felt rejected by her, the one to whom he had been so close.

I was still in junior high school when I was shocked by an incident. It was in Wednesday morning... I was in the classroom studying biology, my sister called the school, asking me to go home. I went home by a taxi-bike. When I got home; my sister, brother, father and mother were in living room. I saw on my mother's hand there were incisions. Then I was told that she had attempted to commit suicide. I was very shocked, I was frozen, unable to speak at all. I just wondered why she could do it. She could have died. Eventually I could say words and I cried. My sister cried too. My brother kept quiet, but I could see him holding his tears while trying to calm me down. For days I just kept quiet, not talking to my mother. I did not care about my family, everything about my home... In fact, I wanted to tell them about my homosexuality. I hadn't had the chance to tell, there had been the incident.

Besides the history of his mother's suicide attempts, his parents' fights also had become the conditioning factors to his suicidal behavior. He said that his mother often had a fight with other members of the family, especially with his father. This made him feel uncomfortable at home.

At home they fight very often, screaming at each other. So dramatic. It's always my mother and other members of the family. My mother had once already brought her luggage, trying to leave the house because of a fight with my father. Before the incident, I had heard from my brother that when he was still at the elementary school, my mother and father always had a fight. My brother used to get rid of all knives from the house so that my mother could not cut her hand.

The relationship between father and mother, the way they communicated made him feel uncomfortable when being around them. He felt his mother was very dominant at home, very often becoming the one who started the fight with his father, demeaning him. He said he never found such condition in other families. As a child he wished that his parents would never fight again, but until his adulthood he still witnessed their fights. He always went out of the house when they had a fight. Such situation made him have problem to act friendly to his mother and to initiate conversation with her.

I find the way my mother talks to my father is like condescending. Everything my father says she always criticises. Sometimes his tone isn't pleasing, and when mother talks, he seems to never listen to her. So, they always talk with unfriendly tones. They just want to say what's in their minds, but never want to listen to each other. That's what makes them often have a fight. I often overhear them fighting, it's like there is a cold war between them, they never discuss their real problems.

He had a strong intention to die when he was still at semester 6 when he broke up with his girlfriend. He got so depressed that he took drugs with doses that kept increasing. He felt his condition got worsen, moreover due to being in distance from his family and being unable to ask support from the family. He had had thought to commit 
suicide but could not find the appropriate way to do it. In the seventh semester, the desire to die was very strong and he read information from the Internet that paracetamol in a large quantity can cause overdose and death. He took 40 pieces of the drug, expecting to die of overdose. However, he did not die, and his friends took him to hospital. After 10 days, he could leave the hospital and began to have therapy sessions with a psychiatrist.

Two months after the first suicide attempt, the desire to die appeared again so strongly that he made an attempt for the second time by hanging using a waistband. He did it twice in a day. His attempts to suicide always failed. He had to go through pain instead. The failures made him think that God had not wanted him to die yet. Therefore, when the idea to die appeared, he harmed himself by cutting his hand and chest.

\section{Acceptance to borderline personality disorder diagnosis}

Borderline Personality Disorder is also known as the factor of suicidal behavior. The participant realized that he had barrier in the relationship with other people because his mood swung easily although he did not know what he really went through. He was diagnosed to have BPD when he was getting the psychiatric service at the hospital after his first suicide attempt. He could accept that diagnosis and it helped him understand himself, especially his mood.

When I knew about my BPD diagnosis, it's like completing a puzzle. At first, I could not find any logical reason. Knowing that I have BPD, I also know why I keep changing to everybody. This is indeed the result of my formation during childhood and it cannot be changed anymore. With this diagnosis, my target with my relationship with other people can be stable without telling them about the diagnosis. Now I still try not to tell everyone and to keep stable. After years trying, the guilty feeling does not disappear, I will keep troubling them. If they pay attention on me, it's like they are wasting their time, and I feel guilty of it. I feel guilty because I trouble them. I choose to avoid social contact. I prefer being on my own.

By accepting his diagnosis, he made up his relationship with other people without telling what happened to him. This acceptance was followed by guilty feeling when receiving attention from other people. He thought that he was a burden for others when they paid attention to him. Hence, he chose to avoid relationship.

\section{Feeling unworthy of love}

The participant felt unworthy of love and attention since early adolescence, which was triggered by the incidents of his mother attempting to commit suicide. No matter how close he was with other people, he always felt alone, and he thought others did not know who he really was, and they would never be able to accept his condition. He said that other people deserved attention, but he did not. Opening himself to others would trouble them and could make him feel guilty. The feelings of unworthiness of attention from others made him avoid interpersonal relations with others. 
I am not used to attention. I feel I don't deserve to get anything from other people. I want to be on my own. Before this (the suicide attempt), I got used to not getting attention. I also get used to being alone, so when I get attention, it hurts me. But I can help other people, care about others because they deserve it. Now when I get a good thing, it's strange for me. It hurts me instead. That makes me remember my faults, my sin (as a bisexual person), including my family, so that what's on my mind is that I should be punished and not get attention like this.

He also felt sinful in relation to his sexual orientation, which is considered infringing the values of the religion he and his family embraced. The sinful feeling made him feel deserve to be punished rather than to be cared.

\section{Ambivalence of sexual orientation}

He went through an ambivalence of his sexual orientation. He disclosed that he was bisexual but his desire to be with and build emotional closeness with a man was bigger than with a woman. He had a drive to be hugged and loved by a man. He used to have a girlfriend, but their relationship lasted for a month because he believed that dating was against his religion. However, it was the happiest experience of his life. When he decided to break up, he got depressed. During the depression period, he did an oral sex with a man. He felt so guilty of it because it is also against his religion, which does not allow its believer to date with other person of different or same gender, moreover to conduct sexual intercourse. It only allows romantic relationship within a marriage. The guilt due to having violated his religion dogmas and the breakup with his girlfriend triggered his first suicide attempt.

In the beginning of 2016, I had a moment with my girlfriend, one night I told her my feeling about her, and she in fact liked me too. Then I told my male friend a month afterwards that I was not close to her anymore because I was reminded that it is against the religion. When I was still close to her, for the first time in 21 years of my life, I was happy, feeling like there was no problem at all at home. After breaking up, I was studying depression in college, and I realize that depression came again.

He did not reveal his sexual orientation to public except to his psychiatrist/ psychologist who treated him, and two male friends who had helped him after trying to commit suicide. He also did not tell his parents and college friends because he thought they were very devoted to their religion so that they would never be able to accept his condition. He was afraid of being rejected because of his sexual identity. He thought that it is very difficult for a religious country like Indonesia to accept individuals with bisexual orientation. Therefore, he avoided social relation and he mingled with several persons from his college only, who knew he was bisexual.

I have a drive to build a close relationship with a man, I really want to be hugged. It's been a long time since the last hug. I feel I like man, perhaps since I was at 4th or 5th grade. Probably at that age I started to like boys and girls. I hadn't known what it's called, but I felt it, but I thought it wasn't right. Feeling as bisexual got stronger during my junior high 
school. My feeling about a girl is the same as about a man. However, the desire to be with a man is stronger than with a girl, because being with a girl I have to marry her legally, but with a man it's easy to cover up.

Becoming an individual from minority sexual orientation group went against the social norms of a heterosexual-dominated society that could not accept individuals with bisexual orientation and was also against the dogma of religion he embraced.

\section{Making meaning of religious values for preventing a fatal suicidal act}

The intention to die and thoughts of suicide often emerged when he was alone or with other people. He realized that the values of his religion states that suicide is a huge sin, and the doer will go to hell. As a Moslem youth who considered himself a religious person, knowing and understand Islamic values, and practicing religious rituals, the values had been instilled in his mind. Every time the thought of suicide came, the religious values also come out. He did not want to die and go to hell, and he tried to obey the teachings of his religion. His perception of the values became the control that defended him from the intention to die and ideation of committing fatal suicide. Non-fatal suicidal behaviors such as cutting his wrist and chest appeared as the forms of suicide thoughts.

The strongest main reason why I did not commit suicide was religion too. Basically, I try to practice my religion, by not committing suicide. In my religion, suicide has a cruel consequence. If I killed myself, I would just move to worse condition. I still can see the reason to not injure myself. Sometimes I cut my own wrist and chest (showing the incision marks on his wrist, and there were incisions that were not dry yet) when the intention to suicide appears. I cannot reject the thought of dying, even now I have the intention to commit suicide.

The suicide ideation also appeared during this study. However, he tried to resist it by reminding himself of the values of his religion. He also tried to participate actively in the students' religious activities in his campus, to listen religious speeches in order to counter the suicide ideation. Religious activities made him keep remembering the religious values that prohibit suicide.

\section{Discussion}

This study aimed to describe what a young bisexual man who experienced BPD does to encounter suicide intention. Previous studies consistently proved that individuals from sexual minority groups are prone to exhibit suicidal behaviors. There were several factors of suicidal behavior risk found in the participant of this study. Conflict between his father and mother since his childhood was one of the factors. He felt alienated and disconnected from the family. In line with previous qualitative study conducted by Diamond et al. (2011), LGB adolescents view family rejection toward their sexual orientation and negative family life events as the sources of psychological distress they experienced. He opted to avoid communication with his parents so that they did not know about his 
history of suicide attempts and his bisexual orientation. Literature has proved that suicidal behavior increases in adolescents who coming from families that often have conflicts and low cohesion (Cerel et al., 2016; Miller et al., 2012). The other factor was the history of his mother's suicide attempts when he was still in his early adolescence. In line with the results of previous studies, the rate of suicide is twice bigger in families that have suicide attempt history and difficult interpersonal relationship (Rajalin et al., 2017; Runeson \& Åsberg, 2003). Besides the history of suicide attempts in the family, the history of psychiatric treatment in hospital and low psychosocial adjustment also become the other factors (Soloff \& Chiappetta, 2012). The participant felt rejected by his mother. His mother's suicide attempt had built an emotional distance between them.

Previous study also consistently found that adolescents with BPD were prone to conduct suicide attempt. The participant of this study has BPD, in which one of the characteristics is mood swing, that he thought to be disruptive to his relationship with others. In order not to hurt others, he limited his relationship with few people only. At the same time, he felt that he was not close to his family. He felt lonely but accepted his BPD's diagnosis. He often cut his wrist or chest. Previous study found in individuals with BPD symptoms history of suicide attempts, impulsiveness, chronic loneliness, and identity disorder significantly relating to lifetime history of non-suicidal self-injury (Brickman et al., 2014); and in the sample of college students who had BPD, suicide ideation increases when social support from family and friends is low (Jeglic et al., 2007). The feeling of hopelessness and a sense of lack connectedness in adolescents happen when they lose romantic relationship and have inadequate social support from family or peer friends (Daniel \& Goldston, 2012).

Initially he felt confused and experienced ambivalence with his sexual orientation. He felt happy with a woman but also has a strong urge to build a romantic relationship with a man and have sex with men. He felt happy to have a girlfriend, but he ended the relationship because he realized that dating is against the teachings of his religion. On the other hand, establishing romantic relationship with men is also opposed by religion. Breaking up with a girlfriend and barriers to building romantic relationships with a man got him depressed. Consistent with previous studies, depression is a risk factor of suicide attempt (Davidson et al., 2011; Handley et al., 2012; Lee et al., 2017). Being a bisexual allowed him to develop a relationship with women, which are more socially acceptable; and camouflaged his urge to be with men, which society tends to reject.

The participant of this study realized that individuals with bisexual orientation could not be accepted in religious countries like Indonesia. The teaching of fundamentalists of the dominant religions in Indonesia, including Islam, tends to increase heterosexism in the society which results in the emergence of homophobia and is demonstrated by violence towards the sexual minority (Ichwan, 2014). Indonesian people indeed consider becoming LGBT as a sin (Saroh \& Relawati, 2017). Therefore, negative standpoint and perception are quite extremely aimed at LGBT groups (Astuti \& Kurniati, 2018). Khoir (2020) conducted a qualitative study on a bisexual and seven gay Muslims in Yogyakarta, aged 20 to 27 years. He found that all participants experienced rejection, 
feelings of isolation and loneliness, related to their sexual orientation and religion. Khoir (2020) explained one of the problems experienced by bisexuals and gays, namely selfrejection related to the internalization of homophobia, so that they have difficulty in accepting their sexual orientation. This condition was also experienced by the participant in this study. He did not come out about his sexual orientation to avoid stigma and rejection. As a young man following Islamic teachings, becoming bisexual and having done oral sex with a man caused him to feel sinful. He withdrew from his social environments to avoid rejection, including from his family and friends. It can be understood, bisexual persons often experience fear to come out as their true selves so that they opts to hide their sexual orientation instead (McLean, 2007).

Consistent with the "minority stress theory", which indicates that the higher the social pressure on bisexual people is, the greater the psychological pressure that is felt which affects their mental health (Meyer, 2003). It was not surprising that the participant testified that when he was alone or with somebody, the thoughts of suicide often emerged. He showed the scarf on his neck from his second and third suicide attempts done before the third meeting with the researcher. The idea appears because the person wants to anticipate rejection towards his sexual orientation (Hill \& Pettit, 2012). Previous studies also found that youths declaring themselves as LBGT and having attempted to suicide consistently report their least amount of psychological resources (self-esteem, family support, and social support) and frequently experiences negative social relationship (Rosario et al., 2005).

The results of this study also showed that the participant experienced a great sinful feeling caused by his multiple suicide attempts. As known, Islam forbids suicide (Ineichen, 1998; Lester, 2006). As a young man who considered himself a religious person, he joined and participated in religious activities in order to cope with his depression and to reduce suicide ideation. Self-declaration as a religious person in some cultures functions as protection from fatal suicidal behaviors (Caribé et al., 2012; Sisask et al., 2010). Systematic reviews also consistently find that religious affiliation and religious service attendance become the mechanism of protection from suicide attempt but not from suicide ideation (Lawrence et al., 2016). The ideation of suicide often came up, but his understanding on the religious values that against suicide helped him overcome his intention to die through attempted suicides. When thoughts of suicide arise, he conducted self-harm. Making meaning of religious values that had been internalised within him appeared as a prevention from fatal suicidal behavior. The religious values could prevent him from committing suicide but not self-harm behavior.

\section{Conclusion}

The study revealed that there are many risk factors that cause a male youth from sexual minority group to conduct suicidal behavior. The result of this study had shown that religiosity plays an important role in preventing a fatal suicidal act, but not self-harm behavior for a bisexual youth. 


\section{Implication}

Implication of this study is to encourage any succeeding study to pay more attention on the process of internalisation and understanding of religious values for preventing suicidal behavior in youths from sexual minority groups. It is also suggested for any future study to pay much attention on the need of bisexual youth to come out amidst the rejection from their social environments.

\section{Acknowledgement}

This manuscript is an internship research, as part of a dissertation at the Faculty of Psychology, Universitas Gadjah Mada. We would like to thank the participant who is willing to be involved in this research and to the Lembaga Pengelolaan Dana Pendidikan (LPDP) who funded the first author's doctoral education.

\section{Authors' contributions}

TDV as the main author who designed the study, submitted the research permit, conducted data collection, and wrote the manuscript. CRM as the main supervisor in the internship program who provided understanding about psychiatric problem experienced by the participant and his dynamics of suicidal behavior. She also conducted the treatment on the participant and recommended the participant for the study. TA as the second supervisor in the internship program who provided advice related to the research method. NRH as the third supervisor in the manuscript writing, who provided overview about suicidal behavior in youths and the direction of theoretical background.

\section{Conflict of interest}

The authors declare no conflict of interest regarding the contents of this manuscript.

\section{Orcid ID}

Tience Debora Valentina 0000-0002-3642-6287

Carla R Marchira 0000-0003-3848-1092

Tina Afiatin 0000-0002-7684-3042

Noor R Hadjam 0000-0002-5075-7488

\section{References}

Aguirre, B. (2014). Borderline personality disorder in adolescent. What to do when your teen has $B P D$ (2nd ed.). Fair Winds Press.

American Psychiatric Association. (2013). Diagnostic and statistical manual of mental disorders-5 (5th edition). American Psychiatric Publishing.

Arora, A. B. (2017). Member checks. In J. Matthes, C. S. Davis, \& R. F. Potter (Eds.), The international encyclopedia of communication research methods (pp. 1-3). John Wiley \& Sons, Inc.

Astuti, D. A., \& Kurniati, N. (2018). Factors influencing stigma to lesbian, gay, bisexual, and transgender (LGBT) among teenagers at Ngaran Village, Gamping, Sleman, Indonesia. Global Health Management Journal, 2(2), 19-24. 
Badgett, M., Hasenbush, A., \& Luhur, W. (2017). LGBT exclusion in Indonesia and its economic effects. The Williams Institute. https://williamsinstitute.law.ucla.edu/wpcontent/uploads/LGBT-Exclusion-in-Indonesia-and-Its-Economic-Effects-March2017.pdf

Biskin, R. S., \& Paris, J. (2012). Diagnosing borderline personality disorder. Canadian Medical Association Journal, 184(16), 1789-1794. https://doi.org/10.1503/cmaj.090618

Björkenstam, C., Kosidou, K., Björkenstam, E., Dalman, C., Andersson, G., \& Cochran, S. (2016). Self-reported suicide ideation and attempts, and medical care for intentional self-harm in lesbians, gays and bisexuals in Sweden. Journal of Epidemiology and Community Health, 70(9), 895-901. http://dx.doi.org/10.1136/jech-2015-206884

Blosnich, J., \& Bossarte, R. (2012). Drivers of disparity: Differences in socially based risk factors of self-injurious and suicidal behaviors among sexual minority college students. Journal of American College Health, 60(2), 141-149. https://doi.org/10.1080/07448481.2011.623332

Bolton, S.-L., \& Sareen, J. (2011). Sexual orientation and its relation to mental disorders and suicide attempts: Findings from a nationally representative sample. Canadian Journal of Psychiatry. Revue Canadienne De Psychiatrie, 56(1), 35-43. https://doi.org/10.1177/070674371105600107

Brickman, L. J., Ammerman, B. A., Look, A. E., Berman, M. E., \& McCloskey, M. S. (2014). The relationship between non-suicidal self-injury and borderline personality disorder symptoms in a college sample. Borderline Personality Disorder and Emotion Dysregulation, 1(1), 14. https://doi.org/10.1186/2051-6673-1-14

Brodsky, B. S., Groves, S. A., Oquendo, M. A., Mann, J. J., \& Stanley, B. (2006). Interpersonal precipitants and suicide attempts in borderline personality disorder. Suicide and Life-Threatening Behavior, 36(3), 313-322. https://doi.org/10.1521/suli.2006.36.3.313

Caribé, A. C., Nunez, R., Montal, D., Ribeiro, L., Sarmento, S., Quarantini, L. C., \& Miranda-Scippa, A. (2012). Religiosity as a protective factor in suicidal behavior: A case-control study. The Journal of Nervous and Mental Disease, 200(10), 863-867. https://doi.org/10.1097/NMD.0b013e31826b6d05

Cerel, J., Frey, L. M., Maple, M., \& Kinner, D. G. (2016). Parents with suicidal behavior: Parenting is not always protective. Journal of Child and Family Studies, 25(7), 23272336. https://doi.org/10.1007/s10826-016-0377-x

Corbin, J. M., \& Strauss, A. (1990). Grounded theory research: Procedures, canons, and evaluative criteria. Qualitative Sociology, 13(1), 3-21. https://doi.org/10.1007/BF00988593

Corbin, J., \& Strauss, A. (2008). Basics of qualitative research: Techniques and procedures for developing Grounded Theory (3rd ed.). SAGE Publications, Inc.

Daniel, S. S., \& Goldston, D. B. (2012). Hopelessness and lack of connectedness to others as risk factors for suicidal behavior across the lifespan: Implications for cognitivebehavioral treatment. Cognitive and Behavioral Practice, 19(2), 288-300. https://doi.org/10.1016/j.cbpra.2011.05.003 
Davidson, C. L., Wingate, L. R., Grant, D. M., Judah, M. R., \& Mills, A. C. (2011). Interpersonal suicide risk and ideation: The influence of depression and social anxiety. Journal of Social and Clinical Psychology, 30(8), 842-855. https://doi.org/10.1521/jscp.2011.30.8.842

Diamond, G. M., Shilo, G., Jurgersen, E., D'Augelli, A., Samarova, V., \& White, K. (2011). How depressed and suicidal sexual minority adolescents understand the causes of their distress. Journal of Gay $\mathcal{E}$ Lesbian Mental Health, 15(2), 130-151. https://doi.org/10.1080/19359705.2010.532668

Gibbs, J. J. (2015). Religious conflict, sexual identity, and suicidal behaviors among LGBT young adults. Archives of Suicide Research: Official Journal of the International Academy for Suicide Research, 19(4), 472-488. https://doi.org/10.1080/13811118.2015.1004476

Glaser, B. G., \& Strauss, A. L. (1967). The discovery of Grounded Theory. Strategies for qualitative research. AldineTransaction.

Handley, T. E., Inder, K. J., Kay-Lambkin, F. J., Stain, H. J., Fitzgerald, M., Lewin, T. J., Attia, J. R., \& Kelly, B. J. (2012). Contributors to suicidality in rural communities: Beyond the effects of depression. BMC Psychiatry, 12, 105. https://doi.org/10.1186/1471-244X-12-105

Hatzenbuehler, M. L. (2011). The social environment and suicide attempts in lesbian, gay, and bisexual youth. Pediatrics, 127(5), 896-903. https://doi.org/10.1542/peds.20103020

Hill, R. M., \& Pettit, J. W. (2012). Suicidal ideation and sexual orientation in college students: The roles of perceived burdensomeness, thwarted belongingness, and perceived rejection due to sexual orientation. Suicide and Life-Threatening Behavior, 42(5), 567-579. https://doi.org/10.1111/j.1943-278X.2012.00113.x

Hottes, T. S., Bogaert, L., Rhodes, A. E., Brennan, D. J., \& Gesink, D. (2016). Lifetime prevalence of suicide attempts among sexual minority adults by study sampling strategies: A systematic review and meta-analysis. American Journal of Public Health, 106(5), e1-12. https://doi.org/10.2105/AJPH.2016.303088

Ichwan, J. (2014). The influence of religion on the development of heterosexism in Indonesia. Religión e Incidencia Pública, 2, 197-223.

Ineichen, B. (1998). The influence of religion on the suicide rate: Islam and Hinduism compared. Mental Health, Religion \& Culture, 1(1), 31-36. https://doi.org/doi:10.1080/13674679808406495

Jeglic, E. L., Pepper, C. M., Vanderhoff, H. A., \& Ryabchenko, K. A. (2007). An analysis of suicidal ideation in a college sample. Archives of Suicide Research, 11(1), 41-56. https://doi.org/10.1080/13811110600897176

Khoir, A. B. (2020). LGBT, Muslim, and heterosexism: The experiences of muslim gay in Indonesia. Wawasan: Jurnal Ilmiah Agama Dan Sosial Budaya, 5(1), 1-19. https://doi.org/10.15575/jw.v5i1.8067

Lawrence, R. E., Oquendo, M. A., \& Stanley, B. (2016). Religion and suicide risk: A systematic review. Archives of Suicide Research: Official Journal of the International 
MEANING OF RELIGIOUS VALUES, SUICIDE ACT, BISEXUAL YOUTH, PERSONALITY DISORDER

Academy for Suicide Research, 20(1), 1-21. https://doi.org/10.1080/13811118.2015.1004494

Lee, C., Oliffe, J. L., Kelly, M. T., \& Ferlatte, O. (2017). Depression and Suicidality in Gay Men: Implications for Health Care Providers. American Journal of Men's Health, 11(4), 910-919. https://doi.org/10.1177/1557988316685492

Lester, D. (2006). Suicide and islam. Archives of Suicide Research: Official Journal of the International Academy for Suicide Research, 10(1), 77-97. https://doi.org/10.1080/13811110500318489

Lewis, R. J., Derlega, V. J., Brown, D., Rose, S., \& Henson, J. M. (2009). Sexual minority stress, depressive symptoms, and sexual orientation conflict: Focus on the experiences of bisexuals. Journal of Social and Clinical Psychology, 28(8), 971-992. https://doi.org/10.1521/jscp.2009.28.8.971

Mavhandu-Mudzusi, A. H., \& Sandy, P. T. (2015). Religion-related stigma and discrimination experienced by lesbian, gay, bisexual and transgender students at a South African rural-based university. Culture, Health \& Sexuality, 17(8), 1049-1056. https://doi.org/10.1080/13691058.2015.1015614

McLean, K. (2007). Hiding in the closet?: Bisexuals, coming out and the disclosure imperative. Journal of Sociology, 43(2), 151-166. https://doi.org/10.1177/1440783307076893

Meyer, I. H. (2003). Prejudice, social stress, and mental health in lesbian, gay, and bisexual populations: Conceptual issues and research evidence. Psychological Bulletin, 129(5), 674-697. https://doi.org/10.1037/0033-2909.129.5.674

Miller, E., McCullough, C., \& Johnson, J. G. (2012). The association of family risk factors with suicidality among adolescent primary care patients. Journal of Family Violence, 27(6), 523-529. https://doi.org/10.1007/s10896-012-9443-3

Miranda-Mendizábal, A., Castellví, P., Parés-Badell, O., Almenara, J., Alonso, I., Blasco, M. J., Cebrià, A., Gabilondo, A., Gili, M., Lagares, C., Piqueras, J. A., Roca, M., Rodríguez-Marín, J., Rodríguez-Jiménez, T., Soto-Sanz, V., Vilagut, G., \& Alonso, J. (2017). Sexual orientation and suicidal behaviour in adolescents and young adults: Systematic review and meta-analysis. The British Journal of Psychiatry: The Journal of Mental Science, 211(2), 77-87. https://doi.org/10.1192/bjp.bp.116.196345

Mustanski, B., \& Liu, R. T. (2013). A Longitudinal Study of Predictors of Suicide Attempts Among Lesbian, Gay, Bisexual, and Transgender Youth. Archives of Sexual Behavior; New York, 42(3), 437-448. http://dx.doi.org/10.1007/s10508-012-0013-9

Page, M. J. L., Lindahl, K. M., \& Malik, N. M. (2013). The role of religion and stress in sexual identity and mental health among LGB youth. Journal of Research on Adolescence: The Official Journal of the Society for Research on Adolescence, 23(4). https://doi.org/10.1111/jora.12025

Plöderl, M., Wagenmakers, E., Tremblay, P., Ramsay, R., Kralovec, K., Fartacek, C., \& Fartacek, R. (2013). Suicide risk and sexual orientation: A critical review. Archives of Sexual Behavior; New York, 42(5), 715-727. http://dx.doi.org/10.1007/s10508-012-0056$\mathrm{y}$ 
Puckett, J. A., Horne, S. G., Surace, F., Carter, A., Noffsinger-Frazier, N., Shulman, J., Detrie, P., Ervin, A., \& Mosher, C. (2017). Predictors of sexual minority youth's reported suicide attempts and mental health. Journal of Homosexuality, 64(6), 697-715. https://doi.org/10.1080/00918369.2016.1196999

Rajalin, M., Hirvikoski, T., Renberg, E. S., Åsberg, M., \& Jokinen, J. (2017). Family history of suicide and interpersonal functioning in suicide attempters. Psychiatry Research, 247, 310-314. https://doi.org/10.1016/j.psychres.2016.11.029

Reich, D. B., \& Zanarini, M. C. (2008). Sexual orientation and relationship choice in borderline personality disorder over Ten years of prospective follow-up. Journal of Personality Disorders, 22(6), 564-572. https://doi.org/10.1521/pedi.2008.22.6.564

Reuter, T. R., Sharp, C., Kalpakci, A. H., Choi, H. J., \& Temple, J. R. (2016). Sexual orientation and borderline personality disorder features in a community sample of adolescents. Journal of Personality Disorders, 30(5), 694-707. https://doi.org/10.1521/pedi_2015_29_224

Rodriguez-Seijas, C., Morgan, T. A., \& Zimmerman, M. (2020). Is there a bias in the diagnosis of borderline personality disorder among lesbian, gay, and bisexual patients? Assessment, 1073191120961833. https://doi.org/10.1177/1073191120961833

Rosario, M., Schrimshaw, E. W., \& Hunter, J. (2005). Psychological distress following suicidality among gay, lesbian, and bisexual youths: Role of social relationships. Journal of Youth and Adolescence, 34(2), 149-161.

Runeson, B., \& Åsberg, M. (2003). Family history of suicide among suicide victims. American Journal of Psychiatry, 160(8), 1525-1526. https://doi.org/10.1176/appi.ajp.160.8.1525

Saroh, Y., \& Relawati, M. (2017). Indonesian youth's perspective towards LGBT. Humanus, XVI(1), 71-82. https://doi.org/10.24036/jh.v16i1.7323

Schuck, K. D., \& Liddle, B. J. (2001). Religious conflicts experienced by lesbian, gay, and bisexual individuals. Journal of Gay $\mathcal{E}$ Lesbian Psychotherapy, 5(2), 63-82. https://doi.org/10.1300/J236v05n02_07

Sisask, M., Varnik, A., Kolves, K., Bertolote, J. M., Bolhari, J., Botega, N. J., Fleischmann, A., Vijayakumar, L., \& Wasserman, D. (2010). Is religiosity a protective factor against attempted suicide: A cross-cultural case-control study. Archives of Suicide Research: Official Journal of the International Academy for Suicide Research, 14(1), 44-55. https://doi.org/10.1080/13811110903479052

Soloff, P. H., \& Chiappetta, L. (2012). Prospective predictors of suicidal behavior in borderline personality disorder at 6-year follow-up. American Journal of Psychiatry, 169(5), 484-490. https://doi.org/10.1176/appi.ajp.2011.11091378

Stone, D. M., Luo, F., Ouyang, L., Lippy, C., Hertz, M. F., \& Crosby, A. E. (2014). Sexual orientation and suicide ideation, plans, attempts, and medically serious attempts: Evidence from local Youth Risk Behavior Surveys, 2001-2009. American Journal of Public Health; Washington, 104(2), 262-271.

Terzi, L., Martino, F., Berardi, D., Bortolotti, B., Sasdelli, A., \& Menchetti, M. (2017). Aggressive behavior and self-harm in borderline personality disorder: The role of 
impulsivity and emotion dysregulation in a sample of outpatients. Psychiatry Research, 249, 321-326. https://doi.org/10.1016/j.psychres.2017.01.011

The Jakarta Post. (2017, January 28). "Indonesia is a religious country": TNI commander. The Jakarta Post. https://www.thejakartapost.com/news/2017/01/28/indonesia-is-areligious-country-tni-commander.html

USAID, \& UNDP. (2014). Being LGBT in Asia: Indonesia Country report (Indonesian Language). 